Chirurgia (2021) 116: 627-633

No. 5, September - October

Copyright@ Celsius

http://dx.doi.org/10.21614/chirurgia.116.5.627

\title{
Management of Epicardial Metastasis in Breast Cancer
}

\author{
Laura Rebegea ${ }^{1,2}$, Ana Maria Ilie ${ }^{1,2}$, Ana Maria Paslaru ${ }^{3}$, Dorel Firescu ${ }^{4,5}$, Cristina Serban ${ }^{4,5}$, Carina Voinescu ${ }^{2}$, \\ Violeta Sapira ${ }^{6}$, Gabriela Stoleriu ${ }^{2}$, Mihaela Lungu ${ }^{2,6}$, Anca Zgura ${ }^{7 *}$, Rodica Anghel ${ }^{7}$
}

'Radiotherapy Department, "Sf. Ap Andrei” Emergency Clinical Hospital Galați, România

2Medical Clinical Department, "Dunărea de Jos" University, Faculty of Medicine and Pharmacy, Galați, România

${ }^{3}$ Medical Department, "Dunărea de Jos" University, Faculty of Medicine and Pharmacy, Galați, România

${ }^{4} I^{\text {nd }}$ Surgery Clinic, "Sf. Ap. Andrei” Emergency Clinical Hospital Galați, România

${ }^{5}$ Surgical Clinical Department, "Dunărea de Jos" University, Faculty of Medicine and Pharmacy, Galați, România

${ }^{6}$ Neurology Clinic "Sf. Ap. Andrei” Emergency Clinical Hospital Galați, România

${ }^{7}$ Carol Davila University of Medicine and Pharmacy, Bucharest, Romania

*Corresponding author:

Anca Zgura, MD

"Carol Davila" University of Medicine and Pharmacy, Bucharest

8 EroilorSanitari Blvd., District 5, code 050474, Bucharest, Romania

E-mail: medicanca@gmail.com

\section{Rezumat}

Managementul terapeutic al metastazelor epicardice în cancerul de sân

Context: Metastazele cardiace pot fi întâlnite mai frecvent decât tumorile cardiace primare. Sunt descoperite la autopsii cu o incidență cuprinsă între 1,5 - 20\%. Tumorile primare care generează metastaze cardiace sunt melanoamele, limfomul, tumorile pulmonare, esofagiene şi de sân. Cel mai afectat organ este pericardul (62-81\%). In 90\% din cazuri din punct de vedere clinic, acestea sunt în general silențioase. În cazul pacientelor diagnosticate cu neoplasm de sân şi care au fost supuse radioterapiei, diagnosticul diferențial cu fibroză după radioterapie interferează. Tratamentul este paliativ şi trebuie administrat în funcție de localizarea primară a tumorii şi de statusul de performanță al pacientei

Prezentare de caz: În lucrarea de față vă prezentăm cazul unei paciente în vârstă de 73 de ani diagnosticata şi tratată pentru un neoplasm de sân în 2006. După o perioadă de timp, 9 ani, în 2015 pacienta este diagnosticată cu determinarea secundară osoasă sternală pentru care a efectuat şedinte de radioterapie şi pentru care se inițiază tratament hormonal. În 2018, pacienta a efectuat evaluare imagistică de etapă care a relevat continuarea de evoluție a bolii prin metastaze pulmonare. La momentul perioadei de urmărire a bolii, efectuată în 2020, este observată din nou o continuare a evoluției bolii, de această dată prin determinări secudare epicardice. 
Concluzie: Metastazele cardiace sunt rare şi, în majoritatea cazurilor, sunt silențioase. Incidența s-a modificat datorită opțiunilor de tratament şi a investigațiilor imagistice performante. Radioterapia stereotactică poate fi considerată o opțiune terapeutică în cazurile cu status de performanță bun şi pentru pacienții diagnosticați cu boală oligometastatică.

Cuvinte cheie: neoplasm sân, metastaze epicardice, radioterapie, chirurgie, chimioterapie

\begin{abstract}
Background: Cardiac metastasis may be encountered more frequently than primary cardiac tumors. They are discovered at autopsies with an incidence between $1.5-20 \%$. The primary tumors that generate cardiac metastasis are malignant melanomas, lymphoma, the lungs, the breast, the esophagus. The organ most affected is the pericardium (62-81\%). In $90 \%$ of cases from a clinical point of view, they are generally silent. In the case of patients diagnosed with breast cancer and who have undergone radiotherapy, differential diagnosis with fibrosis post radiotherapy interferes. The treatment is palliative and should be administered according to the primary location of the tumor and the patient's performance status.

Case presentation: We are presenting the case of a 73-year-old diagnosed and treated for a breast neoplasm in the left breast in 2006. After a period of time of 9 years, the patient presents secondary sternal bone determination, radio-treated and for which she once again goes under hormonal therapy. In 2018, patient performed an imaging evaluation that revealed lung metastases. At the moment of stage review, performed in 2020, secondary epicardial determinations are noted. We present the case, the therapeutic management, diagnostic procedures and treatment and also, we discuss the data from literature.

Conclusion: Cardiac metastases are rare and and in most cases are silent. The incidence has changed due to treatment options and imaging investigations. Stereotactic body radiation therapy can be considereda a therapeutic option in the cases with good performance status and with oligometastatic disease.
\end{abstract}

Key words: breast tumor, epicardial metastases, radiotherapy, surgery, chemotherapy

\section{Introduction}

Cardiac metastasis are more frequent than primary cardiac tumors. They are discovered at autopsies in a percentage between $1.5-$ $20 \%$. The primary tumors that metastasize in heart area are malignant melanomas, lymphoma, the lungs, the breast, the esophagus (1). The most affected organ is the pericardium (62-81\%). From a clinical point of view, in almost $90 \%$ of cases, they are generally silent (2).

In the case of breast cancer, differential diagnosis is difficult and might be confused with fibrosis post radiotherapy. The treatment is palliative and should be administered according to the primary location of the tumor and the patient's performance status. Primary or metastatic cardiac tumors are rare, but when malignant, they have poor prognosis (3).

The incidence of heart metastases is increasing, reaching just over $10 \%$. Neoplasms that metastasize to the heart can be divided into three categories of incidence: (1) primary tumors that have a high rate of metastasis to the heart including malignant melanoma, germ cell malignancy, malignant thymoma, (2) malignant tumors with an intermediate rate of cardiac metastasis, and represents the highest number of cardiac metastases (carcinoma of the stomach, liver, ovary, colon and rectum), (3) tumors that rarely metastasize to the 
heart. There are four ways in which noncardiac tumors can invade the heart: direct mediastinal infiltration of heart tissue in lung cancer, breast cancer or mediastinal lymphoma, hematogenous spread through systemic tumors, such as malignant melanoma, lymphoma, leukemia, or sarcoma, venous spread from the inferior vena cava in the case of renal or liver tumors and from the pulmonary vein in the case of lung cancer; and the last mode of invasion represented by lymphatic spread $(4,5)$.

\section{Case Presentation}

We present a case of breast cancer in a female patient, 73 years old, with heart metastases developed after 14 years from diagnosis and treatment of the primary tumor. The patient's past medical history was significant for a leftsided total mastectomy with axillary dissection for carcinoma in 2006, in the Institute of Oncology Bucharest; histological diagnosis was well-differentiated ductal invasive carcinoma of the breast.

The patient was staged as ypT1aN2M0, 8 lymph nodes were positive; Immunohistochemistry (IHC) revealed: positive estrogen receptors (ER+) 40\%, positive progesterone receptors $(\mathrm{PR}+)$ 5\%, human epidermal growth factor receptor 2 (HER-2/neu) was negative and proliferation index Ki 67 was $15 \%$.

At that time, she underwent chemotherapy (3 cycles, protocol AC: doxorubicin/ciclofosfamide) and adjuvant radiation therapy $(\mathrm{RT})$, total dose $(\mathrm{TD})=50 \mathrm{~Gy} / 25$ fractions on target volumes: chest wall, axillary lymph nodes (level I, II, III), and supraclavicular lymph nodes, at Sf. Apostol Andrei Emergency Clinical Hospital of Galati, Department of Radiotherapy; also, she received hormonal therapy with aromatase inhibitors, letrozole during 2005-2013.

Disease free survival was 9 years. In May 2015 , the patient was diagnosed by bone scintigraphy with unique sternal bone metastases which were treated by radiotherapy $\mathrm{TD}=37.5 \mathrm{~Gy} / 15$ fractions, 2.5Gy/ fraction with good clinical outcome.
Subsequently, she was treated with another hormone treatment regimen, tamoxifen for three years. Between 2015 and 2017, periodic evaluations revealed tumor regression without new metastases. In 2017 , on a regular oncological follow-up with computed tomography scan (CT) the patient was diagnosed with pulmonary nodes in the left lung lobe (LSS) $6 / 15 \mathrm{~mm}$, and tumors marker carbohydrate antigen $15-3(\mathrm{CA} 15-3)=30.51 \mathrm{U} / \mathrm{ml}$. In December 2017, after performing the PETCT that identified two subpleural nodules (8$10 \mathrm{~mm}$ ) located in the left cardio-phrenic angle with FDG uptake (SUV max 4.1) for which the atypical resection was performed in January 2018 at Marius Nasta Institute of Pneumology. The histopathological report was carcinomatous tumor proliferation, without infiltration of the visceral pleura (PLO), lymphatic invasion present (L1), vascular invasion present (V1), and IHC test revealed ER 30\%, HER2 overexpression, KI 67 20\%, chromogenic in situ hybridization (CISH) negative.

In February 2018, a CT scan showed disease progression by two solid iodophilic nodes in epicardial adipose tissue with a diameter of $6 / 9 \mathrm{~mm}$ ) and high values of tumor marker CA 15-3= 41.38U/ml suggested clinical relapse, and she started second line hormonal therapy with fulvestrant and letrozole; also, in December 2018, capecitabine was initiated.

In June 2020, after 27 months of hormone treatment and 18 months of capecitabine, a complete CT imagistic re-evaluation (Fig. I) describe two solid iodophilic nodes in epicardial adipose tissue with a diameter of $11 / 9 \mathrm{~mm}$ and $12.5 / 9 \mathrm{~mm}$, respectively, one of these being in dimensional progressive respect of previous scan. This was confirmed by positron emission tomography (PET-CT) scan from July 2020 (Fig. 2).

PET-CT (July 2020) highlighted 2 small lesions with metabolic activity $\mathrm{SUV}=3.73$ in left anterior cardiophrenic region (Fig. 2). Clinically, the patient was asymptomatic, with good performance status, IP=0, Eastern Cooperative Oncology Group Performance Status Scale (ECOG PS).

Cardiovascular examination revealed no 


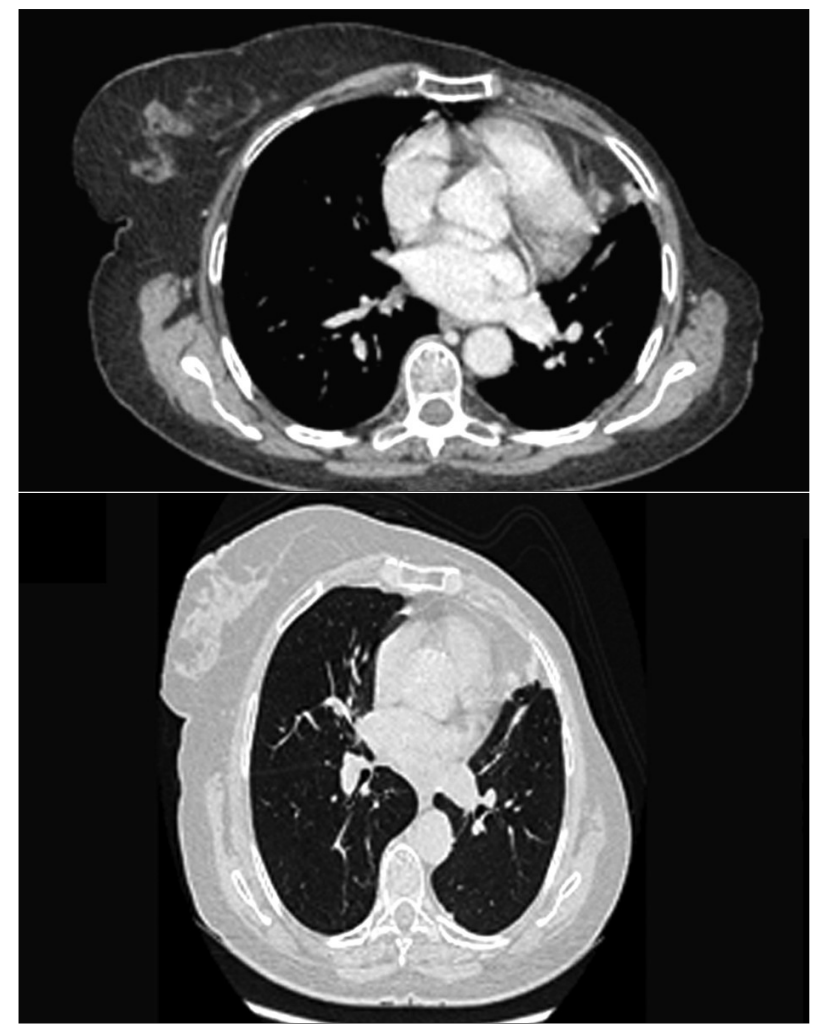

Figure 1. CT scan from June 2020

pathological electrocardiographic changes, blood pressure of 140/70 mmHg; echocardiography revealed no dilated left ventricle with global systolic function in normal limits, left ventricle ejection fraction $65 \%$, diastolic dysfunction type late relaxation, minor mitral regurgitation without hemodynamic significance, without ultrasound sings of intrapulmonary hypertension.

She was candidate for palliative radiation therapy, SBRT, which was delayed until the

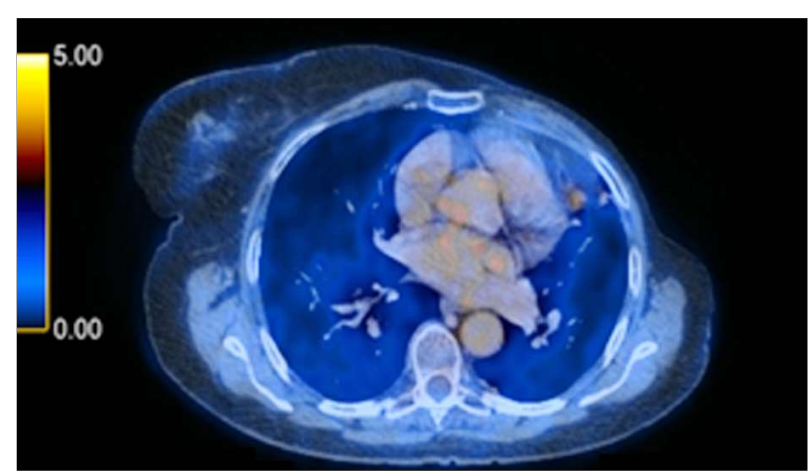

Figure 2. PET-CT July 2020 moment of writing this article. Two previous irradiations (chest wall, in 2D technique and sternal bone, in 3D conformal therapy) and anthracycline toxicity should be considered in order to perform the SBRT treatment plan.

\section{Discussion}

Although primary cardiac tumors are rare, secondary are not, and the exact incidence of cardiac metastasis is unknown (5-7). About $2 / 3$ of all heart metastases are in the pericardium and only $1 / 3$ are in the epicardium or myocardium (8). The main sites of breast cancer metastasis are the bones, lungs, regional lymph nodes, liver, and brain.

The diagnosis of cardiac metastases in patients with advanced neoplasms has become easier to identify due to modern imaging techniques, which has also led to an increase in survival (9).

There is no strong correlation between the extent of cardiac metastases and clinical symptomatology. The symptomatology and clinical presentation may vary depending on location or the tnumber of metastases and can be classified as extra cardiac (constitutional and mechanical), cardiac (pericardial, myocardial and intracavitary), or combined (10).

It is difficult to make a differential diagnosis between cardiac metastases and other heart diseases due to the fact that it manifests itself in the same way by including dyspnea, palpitations, atrial flutter or fibrillation, lower-extremity edema, and chest pain. Cardiac metastasis may also present with dramatic and life-threatening manifestations like cardiac tamponade from pericardial involvement, which is a medical emergency.

Echocardiography represents the initial method to detect pericardial effusions and to assess the presence and clinical consequences of any cardiac metastasis. Cardiac magnetic resonance imaging (CMR), computed tomography, and positron emission tomography can provide additional information of cardiac masses. Even if the imaging is suspicious of cardiac metastases, the definite diagnosis is made on the basis of histopathological exami- 
nation, which differentiates metastatic from non-metastatic lesions.

Although exploratory thoracotomy and open biopsy is sometimes necessary to identify cardiac metastases, various techniques for obtaining tumor cells do not require thoracic surgery. Malignant cells can be identified in the majority of malignant pericardial effusions drained by pericardiocentesis, and the cytology of malignant cells has an extraordinarily high correlation with the histological diagnosis. The most important goals of intervention should include palliation of symptoms and prevention or delay of symptom recurrence (11).

Management of malignant cardiac tumors has always been a challenge for cardiac surgeons due to invasive growth and limitations of resection inside the heart (12).

Despite significant advances in the treatment of cancer, no standard-of-care exists for treating patients with cardiac metastases. These patients have a poor prognosis, the decision of whether and how they can be treated is difficult (13).

Surgical resection in rare cases is generally reserved for cases in which prognosis is otherwise good, for patients in whom complete resection is technically feasible, or for specific cases of intracardiac obstruction. Decision of heart surgery may be difficult and must take into consideration the post-surgery complications.

Intracardiac obstruction by cardiac metastases may require surgery, although outcomes may be poor if ventricular function has been irreversibly compromised (14). The resection of cardiac metastasis can offer, theoretically, maximum local control (15).

Radiotherapy and chemotherapy can also be useful for the treatment of cardiac metastases. Data about palliative radiotherapy from the literature are limited It is therefore important to involve a multidisciplinary team in the evaluation and management of the patient with cardiac metastasis. The use of palliative radiotherapy in the management of these patients has been limited presumably due to technical difficulties limiting the ability to safely deliver a clinically useful radiation dose to the heart and/ or the concern about radiation-induced toxicity. The risk is associated with the radiation dose, treatment duration, and radiation volume (16).

Re-irradiation for cardiac metastases is difficult in this case due to the late cardiotoxicity after treatment with anthracycline, used as the first line of treatment, after 2D radiotherapy and after $3 \mathrm{D}$ conformal radiotherapy for sternal bone metastases. Considering the long-term hematological and cardiac toxicity induced by anthracyclines, the importance of regimen and dose density chosen in breast cancer patients and their necessity in the adjuvant setting might be indicated by several tissue biomarkers assessable through immunohistochemistry (IHC) techniques, allowing for the choice of personalization of treatment (17-19).

Cardiac radiotherapy for radiationsensitive cardiac tumor seems a reasonable treatment, but is rarely used in clinical practice, probably because of the rarity of clinical evident cardiac tumors and for concerns of cardiac toxicity from radiation. Few case reports and small case series have described various cardiac tumors and most of which showed symptomatic or image resolution after cardiac radiotherapy (20).

Despite its inability to cure metastatic cancer, cardiac radiotherapy has beneficial effects on transient local tumor control, symptomatic relief, and may improve life quality.

There are few studies in specialty literature regarding radiotherapy delivered to the heart. One of these is the study by Ghiam et al. which analyzed patients who received RT to the heart, in Princess Margaret Cancer Centre, Canada; ten patients with muralbased metastatic deposits in the heart from various histologies were identified between 2003 and 2014, three of them received radiotherapy alone with palliative intent, in 3DCRT, IMRT, VMAT techniques. It appears that the total radiation dose of 30-45 Gy in 1.8-2 Gy per fraction is safe, effective, and desirable to provide symptom control in patients with cardiac metastases. Radio- 
therapy was very well-tolerated in all cases, with few acute side effects with complete or partial resolution of symptoms. Using simple techniques, palliative radiotherapy was effective to relieve distressing symptoms of dyspnea, palpitation, and chest pain in these cases. The documented duration of response was between 3 and 11 months in these patients, and treatment was associated with low toxicity. The irradiation of cardiac metastases should be considered in the management of these patients, especially when we have no other therapeutic options (21).

Katalinic et al. (3) published a case in 2013 of a 64-year-old woman with a history of breast cancer diagnosed and treated who developed cardiac metastases after 27 years from primary tumor treatment. The patient presented at the hospital with dyspnea and orthopnea, with IP=4 (ECOGPS) and she was diagnosed with cardiac metastases. The patient received symptomatic treatment and palliative RT was also initiated, but because of the patient's severe general condition, a total dose of only $6 \mathrm{~Gy} /$ day was delivered as palliative thoracic radiotherapy, but without an improvement in her general condition (22).

Another study published by Bonomo, based on the experience of the University of Florence, concluded that the use of SBRT for the treatment of cardiac and paracardiac metastases is a safe and effective option (23).

Ernst et al. (24) published a very important article in 2019 analyzing 17 patients (4 with relapsed cardiac sarcoma, 13 with cardiac or paracardiac metastases) and bringing an important contribution to management of cardiac and paracardiac tumor, taking into consideration paucity of literature data. These patients were treated with stereotactic body radiotherapy (SBRT) which was effective and well-tolerated.

Due to the experience gained on the benefits of adjuvant RT for soft tissue sarcoma in terms of local control in primary tumors, it was concluded that certain cases with cardiac metastases may benefit from adjuvant RT for good local tumor control and may improve palliative control (25).
Radiation therapy can cause thrombosis of the tumor by obstructing blood flow to the tumor. If high doses are used, an arterial embolism or rupture of the vessel wall may occur (26). Arrhythmias or other heart conditions present in these patients could further complicate treatment (27).

Another issue that can be debated is the relationship between the patient and the physician who a supportive role, a relationship which must be based on trust and reciprocity, when communication is open, sincere and fully honest. Supportive psychotherapy must focus on solutions, and in all medical cases, supportive groups may be efficient by sharing individual experiences, such as patient groups with the same diagnosis or patient groups with the same therapeutical sequence (28).

\section{Conclusion}

Epicardial metastases are rare and frequently silent. The treatment is palliative and must be individualized according to the location of the primary tumor and the status of performance of the patient. Patients should be monitored for the appearance of a second neoplastic location.

Clinicians must take into consideration cardiac metastases even in the absence of clinical symptomatology, and, also, must consider cardiac metastases for differential diagnosis in patients with neoplastic history.

No standard-of-care therapy exists for the management of patients with cardiac metastases. It is recommended that irradiation of cardiac metastases should be considered early in the management of treatment of these patients, particularly when other treatment options are not feasible or do not seem promising. SBRT represents a safe and effective treatment option for patients with cardiac and paracardiac metastases. The optimal radiotherapy dose and fractionation should be individualized based on: patient's characteristics, tumor characteristics, and treatment-related factors, such as history of previous thoracic radiotherapy and the use of anthracyclines. 


\section{References}

1. Virmani R. Tumours metastatic to the heart and pericardium. In: Burke A, Virmani R, eds. Atlas of tumour pathology. Tumours of the heart and great vessels. 3rd Series Fascicle 16. Washington, DC: AFIP; 1995. p. 195-209.

2. McAllister H A Jr. Tumours of the heart and pericardium. In: Silver MD, ed. Cardiovascular pathology. Vol 2, 2nd edn. New York, NY: Churchill Livingstone; 1991. p. 1297-1333.

3. Fotouhi Ghiam A, Dawson LA, Abuzeid W, Rauth S, Jang RW, Horlick E, et al. Role of palliative radiotherapy in the management of mural cardiac metastases: who, when and how to treat? A case series of 10 patients. Cancer Med. 2016;5(6):989-96.

4. Catton C. The management of malignant cardiac tumors: clinical considerations. Semin Diagn Pathol. 2008;25(1):69-75.

5. Katalinic D, Stern-Padovan R, Ivanac I, Aleric I, Tentor D, Nikolac N, et al. Symptomatic cardiac metastases of breast cancer 27 years after mastectomy: a case report with literature review - pathophysiology of molecular mechanisms and metastatic pathways, clinical aspects, diagnostic procedures and treatment modalities. World J Surg Oncol. 2013; 11:14.

6. Bussani R, De-Giorgio F, Abbate A, Silvestri F. Cardiac metastases. J Clin Pathol. 2007;60(1):27-34. Epub 2006 Nov 10.

7. Goldberg AD, Blankstein R, Padera RF. Tumors metastatic to the heart Circulation. 2013:128(16):1790-4.

8. Karwinski B, Svendsen E. Trends in cardiac metastasis. APMIS. 1989; 97(11):1018-24.

9. Bacinschi XE, Zgura A, Safta I, Anghel R. Biomolecular factors represented by $\mathrm{Bcl}-2$, p53, and tumor-infiltrating lymphocytes predict response for adjuvant anthracycline chemotherapy in patients with early triple-negative breast cancer. Cancer Manag Res. 2020;12:11965-11971.

10. Young JM, Goldman IR. Tumor metastasis to the heart. Circulation. 1954; 9(2):220-9.

11. Azim HA Jr, de Azambuja E, Colozza M, Bines J, Piccart MJ. Longterm toxic effects of adjuvant chemotherapy in breast cancer. Ann Oncol. 2011;22(9): 1939-1947.

12. Ghigo A, Li M, Hirsch E. New signal transduction paradigms in anthracycline-induced cardiotoxicity. Biochim Biophys Acta. 2016;1863(7 Pt B):1916-25.

13. Praga C, Bergh J, Bliss J, Bonneterre J, Cesana B, Charles Coombes R, et al. Risk of acute myeloid leukemia and myelodysplastic syndrome in trials of adjuvant epirubicin for early breast cancer: correlation with doses of epirubicin and cyclophosphamide. J Clin Oncol. 2005;23(18): 4179-91.

14. Hamidi M, Moody JS, Weigel TL, Kozak KR. Primary cardiac sarcoma. Ann Thorac Surg. 2010;90(1):176-81.

15. Sapir E, Tao Y, Schipper MJ, Bazzi L, Novelli PM, Devlin P, et al. Stereotactic body radiation therapy as an alternative to transarterial chemoembolization for hepatocellular carcinoma. Int J Radiat Oncol Biol Phys. 2018;100(1): 122-130. Epub 2017 Sep 14

16. Truong PT, Jones SO, Martens B, Alexander C, Paquette M, Joe H, et al. 2009. Treatment and outcomes in adult patients with primary cardiac sarcoma: the British Columbia Cancer Agency experience. Ann Surg Oncol. 2009;16(12):3358-65

17. Hamidi M, Moody JS, Weigel TL, Kozak K. R. 2010. Primary cardiac sarcoma. Ann Thorac Surg. 2010;90(1):176-81.

18. Bakaeen FG, Jaroszewski DE, Rice DC, Walsh GL, Vaporciyan AA, Swisher SS, et al. 2009. Outcomes after surgical resection of cardiac sarcoma in the multimodality treatment era. J Thorac Cardiovasc Surg. 2009; 137(6): 1454-60.

19. Carver JR, Shapiro CL, Ng A, Jacobs L, Schwartz C, Virgo KS, et al. 2007. ASCO Cancer Survivorship Expert Panel. American Society of Clinical Oncology clinical evidence review on the ongoing care of adult cancer survivors: cardiac and pulmonary late effects. J Clin Oncol. 2007;25(25): 3991-4008.

20. Magnuson WJ, Halligan JB. Successful treatment of melanoma metastatic to the left atrium using external beam radiation therapy. Oncology (Williston Park). 2010;24(7):650-3

21. Dasgupta T, Barani IJ, Roach M 3 $3^{\text {rd }}$ 2011. Successful radiation treatment of anaplastic thyroid carcinoma metastatic to the right cardiac atrium and ventricle in a pacemaker-dependent patient. Radiat Oncol. 2011;6:16.

22. Katalinic A, Eisemann N, Kraywinkel K, Noftz MR, Hübner J. Breast cancer incidence and mortality before and after implementation of the German mammography screening program. Int J Cancer. 2020;147(3):709-718.

23. Bonomo P, Livi L, Rampini A, Meattini I, Agresti B, Simontacchi G, et al. Stereotactic body radiotherapy for cardiac and paracardiac metastases: University of Florence experience. Radiol Med. 2013;118(6):1055-65.

24. Poole GV Jr, Meredith JW, Breyer RH, Mills SA. Surgical implications in malignant cardiac disease. Ann Thorac Surg. 1983;36(4):484-91.

25. Erin N, Kale S, Tanriöver G, Köksoy S, Duymus 0, Korcum AF. Differential characteristics of heart, liver, and brain metastatic subsets of murine breast carcinoma. Breast Cancer Res Treat. 2013;139(3):677-89.

26. Cuculich PS, Schill MR, Kashani R, Mutic S, Lang A, Cooper D, et al. Noninvasive cardiac radiation for ablation of ventricular tachycardia. N Engl J Med. 2017:377(24):2325-2336.

27. Cooper LT, Baughman KL, Feldman AM, Frustaci A, Jessup M, Kuhl U, et al. 2007. The role of endomyocardial biopsy in the management of cardiovascular disease: a scientific statement from the American Heart Association, the American College of Cardiology, and the European Society of Cardiology. Endorsed by the Heart Failure Society of America and the Heart Failure Association of the European Society of Cardiology. J Am Coll Cardiol. 2007;50(19):1914-31

28. Popa-Velea 0, Bacinschi X. Dynamics of anxiety in cervical cancer patients undergoing radiotherapy: preliminary results. J Psychosom Res 2019; $121: 135$. 